\title{
Iron(II) modified natural zeolites for hexavalent chromium removal from contaminated water
}

\author{
Antonio Lofù ${ }^{1}$, Piero Mastrorilli ${ }^{1}$, Maria Michela Dell'Anna ${ }^{1 *}$, Matilda Mali ${ }^{1}$, Raffaello Sisto ${ }^{2}$, \\ Rodolfo Vignola ${ }^{2}$ \\ ${ }^{1}$ Politecnico di Bari, Italy \\ DICATECh \\ ${ }^{2}$ Centro Ricerche Monterotondo, Italy \\ ENI S.p.A. Refining and Marketing Division
}

${ }^{*}$ Corresponding author’s e-mail: mariamichela.dellanna@poliba.it

\begin{abstract}
Keywords: $\mathrm{Cr}$ abatement, natural zeolites, water remediation, ferrous iron.
Abstract: Three different types of Fe(II)-modified natural zeolites were tested as supports in continuous-flow columns for the treatment of $\mathrm{Cr}(\mathrm{VI})$ contaminated water. The natural zeolites chosen as support were commercially available Zeosand (80\% clinoptilolite), ATZ (79\% phillipsite/chabazite), and ZS-55RW (90\% Chabazite). All the examined modified zeolites turned out active for hexavalent chromium abatement, lowering its concentration below the European regulation level, even at relatively high flow rates $(40 \mathrm{~mL} / \mathrm{h}$, linear velocity $15 \mathrm{~cm} / \mathrm{h})$. Zeosand, having a broader $\mathrm{pH}$ range of stability, was found to be the best one in terms of both Fe(II) uptake $(0.54 \mathrm{wt} \%)$ and Cr removal (90 mg $\mathrm{Cr} / \mathrm{Kg}$ zeolite).
\end{abstract}

\section{Introduction}

Chromium exists in the environment in two valence states: $\mathrm{Cr}(\mathrm{III})$, which occurs naturally and is an essential nutrient, and $\mathrm{Cr}(\mathrm{VI})$, which is toxic and is most commonly produced by industrial processes (Hug et al. 1997, Kotaś and Stasicka 2000, Loyaux-Lawniczak et al. 2001). Cr(III) forms insoluble $\mathrm{Cr}(\mathrm{OH})_{3}$ between $\mathrm{pH} 6$ and $\mathrm{pH} 12$; moreover, it can be strongly adsorbed on soil particles or immobilised by complexation with macromolecular ligands such as humic substances. $\mathrm{Cr}(\mathrm{VI})$ species are much more soluble and mobile and are only weakly sorbed to inorganic surfaces such as metal oxides; within the $\mathrm{pH}$ and $\mathrm{pE}$ range of natural waters $\mathrm{Cr}(\mathrm{VI})$ is present in solution mainly as $\left[\mathrm{HCrO}_{4}\right]^{-}$or $\left[\mathrm{CrO}_{4}\right]^{2-}$.

According to current Italian regulations (Italian D. Lgs. 152/2006) the maximum allowed chromium concentration for groundwater in contaminated sites is $50 \mu \mathrm{g} / \mathrm{L}$ for total chromium and $5 \mu \mathrm{g} / \mathrm{L}$ for $\mathrm{Cr}(\mathrm{VI})$; the European drinking water standard for total $\mathrm{Cr}$ is $50 \mu \mathrm{g} / \mathrm{L}$ (Directive 98/83/CE).

Several in situ and on site $\mathrm{Cr}(\mathrm{VI})$ remediation strategies are available, depending on the geologic or hydrologic characteristics of the soils and aquifers, namely reactive zones, pump\&treat methods, electrochemical or biochemical methods, permeable reactive barrier (PRB) technologies (Fruchter 2002, Mackay and Cherry 1989, Palmer and Wittbrodt 1991, Rama Krishna and Philip 2005, Zayed and Terry 2003).

There are two approaches for the chromate remediation: (i) $\mathrm{Cr}$ (VI) removal by ion exchange or sorption on suitable materials, or (ii) $\mathrm{Cr}(\mathrm{VI})$ reduction to the less toxic and mobile Cr(III).
An example of the first approach is the use of synthetic resins (Gode and Pehlivan 2005, Rengaraj et al. 2003, Zhao et al. 1998) or modified natural zeolites (Barrer 1978, Campos et al. 2007, Faghihian and Bowman 2005, Li 2006, Misaelides et al. 2008, Rhodes 2007, Robson 2001, Vignola et al. 2008, Zeng et al. 2010, Li and Hong 2009), since the affinity of zeolites for anionic species can be greatly enhanced by modification with certain cationic surfactants or suitable cations or even bacteria (Erdogan et al. 2012).

In fact, zeolites are micro- and nano-porous aluminosilicates that are widely employed for cation exchange, catalysis, and remediation of metals in wastewaters (Wu et al. 2008, Liguori et al. 2006, Inglezakis et al. 2003). The $\mathrm{CrO}_{4}^{2-}$ anion is not strongly adsorbed on unmodified zeolite due to permanent, structural negative charge of the crystal lattice (Meir et al. 2001). However, cationic surfactant-modified zeolite has been shown to be an effective $\mathrm{Cr}(\mathrm{VI})$ adsorbent (Leyva-Ramos et al. 2008). On the contrary, the $\mathrm{Cr}$ (III) cation is strongly adsorbed by a variety of natural and synthetic zeolites (Inglezakis et al. 2003).

The reduction of $\mathrm{Cr}(\mathrm{VI})$ to $\mathrm{Cr}(\mathrm{III})$ by a variety of inorganic and organic reductants has been recognised as an important remedial strategy, since $\mathrm{Cr}$ (III) can be then immobilised as insoluble hydroxides and oxyhydroxides (Rai et al. 1987) or adsorbed by naturally distributed earth materials, such as zeolites. Once reduced to $\mathrm{Cr}(\mathrm{III})$, the reoxidation to $\mathrm{Cr}(\mathrm{VI})$ is disfavoured in natural groundwater environments and is thought to be limited to the action of oxygen and manganese oxide as oxidants (Eary and Rai 1987, Hwang et al. 2002, Schlautman and Han 2001, Sung and Morgan 1980). The most 
commonly used reductants are iron metal, ferrous iron or sulfur compounds for chemically engineered processes (Ludwig et al. 2007, Martin and Kempton 2000, Patterson et al. 1997, Qin et al. 2005, Yang et al. 2007), and organic materials for biological remediation (Rama Krishna and Philip 2005, Tokunaga et al. 2003). An advantage of this technique is that $\mathrm{Cr}(\mathrm{VI})$ reduction by $\mathrm{Fe}(\mathrm{II})$ at $\mathrm{pH}$ values between 5 and 11 occurs with the formation of an insoluble $\mathrm{Fe}$ (III)-Cr(III) (oxy)hydroxide, lowering $\mathrm{Cr}$ (III) concentrations in water down to $10^{-6} \mathrm{M}$ (Eary and Rai 1988). The ability of Fe(II) salts to reduce and immobilize $\mathrm{Cr}(\mathrm{VI})$ in contaminated soils have been studied in both batch and column experiments.

The use of both zerovalent (Bowman and Helferich 2001, Li et al. 1999, Li et al. 2007, Vignola et al. 2007) and divalent iron (Dimirkou and Doula 2008, Doula 2007, Litz 2006, Kiser et al. 2010, Lu et al. 2013) modified zeolites represents an interesting combination of the two above mentioned strategies, and its effectiveness in chromate abatement from aqueous media has been reported.

In this paper we report a laboratory column study on the use of Fe(II)-modified natural zeolites of different composition for $\mathrm{Cr}(\mathrm{VI})$ removal in continuous-flow systems, which may represent a treatment medium suitable for pump\&treat and PRB technologies.

\section{Experimental}

\section{General}

Zeolites were purchased from "G. Apostolico \& N. Tanagro s.n.c.”, Naples, Italy (ATZ), “Zeo Inc.”, US (ZEOSAND) and "GSA Resources Inc.", US (ZS-500RW). Cr(VI) adsorption tests on unmodified zeolites were carried out in vials containing $500 \mathrm{mg}$ of Zeosand or ZS-500RW and $40 \mathrm{~mL}$ of $\mathrm{Cr}(\mathrm{VI})$ solutions with a concentration ranging from 50 to $500 \mu \mathrm{g} / \mathrm{L}$ which were left $24 \mathrm{~h}$ under stirring. A sample of the solution was directly analysed to determine the $\mathrm{Cr}$ content after filtration.

\section{$\mathrm{Fe}(\mathrm{II})$-modified zeolite preparation}

$200 \mathrm{~g}$ of commercial zeolite material was immersed in $80 \mathrm{~g} / \mathrm{L}$ solution of $\mathrm{FeSO}_{4} \cdot 7 \mathrm{H}_{2} \mathrm{O}$ in nitrogen atmosphere under vigorous stirring. The system was allowed to equilibrate within $48 \mathrm{~h}$. The exchange was repeated twice, successively the zeolite was fully rinsed with deionized water $(4 \times 100 \mathrm{~mL})$ to remove any $\mathrm{Fe}(\mathrm{II})$ not specifically adsorbed on the support, dried under vacuum and sieved through a $0.5 \mathrm{~mm}$ sieve to remove smaller particles and any degraded material. The Fe(II)-modified zeolites were stored under nitrogen and used as soon as prepared. The Fe content was determined by hot nitric acid (65\%) extraction $(4 \mathrm{~mL})$ on a sample $(10 \mathrm{mg})$ of untreated zeolite and Fe(II)-modified zeolite.

\section{Column studies}

In a typical experiment a Plexiglas column $(20 \mathrm{~cm}$ length, $2.6 \mathrm{~cm}$ ID) with Teflon caps was packed with freshly prepared $\mathrm{Fe}(\mathrm{II})$-modified zeolite; the treatment system was equipped with a Gilson MiniPuls3 peristaltic pump. The elution of contaminant solution $(500 \mu \mathrm{g} / \mathrm{L}$ of $\mathrm{Cr}(\mathrm{VI})$ and $15 \mathrm{~g} / \mathrm{L}$ of $\mathrm{NaCl})$ was performed in upflow at a flow rate of $0.040 \mathrm{~L} / \mathrm{h}, 15 \mathrm{~cm} / \mathrm{h}$. The target point on the breakthrough curve was taken as the pore volume at which the $\mathrm{Cr}$ concentration of the effluent overcomes $5 \mu \mathrm{g} / \mathrm{L}$ (the legal Italian limit). Samples of the effluent $(40 \mathrm{~mL})$ were collected at time intervals and analysed for $\mathrm{Fe}$ and $\mathrm{Cr}$ content. $\mathrm{Fe}$ and $\mathrm{Cr}$ analyses were performed with a Perkin-Elmer SIMAA6000 graphite furnace atomic adsorption spectrometer equipped with an auto sampler.

\section{Results and Discussion}

The commercially available natural zeolites having different structure and origin, chosen as model in this study, are clinoptilolite (Texas, USA, ZEOSAND), chabazite (Arizona, USA, ZS-500RW) and phillipsite (Campania, Italy, ATZ). The principal properties of these natural zeolites are reported in Tables 1 and 2.

Table 1. Properties of used zeolites

\begin{tabular}{|c|c|c|c|c|c|c|c|}
\hline \multirow{2}{*}{ Zeolite } & \multirow{2}{*}{$\begin{array}{l}\text { Zeol. } \\
\text { content }\end{array}$} & \multirow{2}{*}{$\begin{array}{l}\text { Abs. } \\
\text { Density } \\
\left(\mathrm{g} \mathrm{cm}^{-3}\right)\end{array}$} & \multirow{2}{*}{$\begin{array}{c}\text { CEC } \\
\left(\text { meq g }^{-1}\right)\end{array}$} & \multirow{2}{*}{$\begin{array}{c}\text { Stability } \\
\text { (pH) }\end{array}$} & \multicolumn{3}{|c|}{ Grain size fraction (\%) } \\
\hline & & & & & $0.20 \div 0.42 \mathrm{~mm}$ & $1.0 \div 1.3 \mathrm{~mm}$ & $2.0 \div 2.5 \mathrm{~mm}$ \\
\hline ATZ & $\begin{array}{c}\text { Phillip./Chab. } \\
79 \%\end{array}$ & 2.10 & 1.95 & $4 \div 8$ & 59 & 41 & - \\
\hline ZS-500RW & Chab. 90\% & 1.73 & 2.50 & $3 \div 12$ & 12 & 46 & 42 \\
\hline ZEOSAND & Clinopt. $80 \%$ & $\sim 2$ & 1.50 & $3 \div 11$ & 53 & 47 & - \\
\hline
\end{tabular}

Table 2. Chemical composition of zeolites

\begin{tabular}{ccccccccccccc}
\hline \multirow{2}{*}{ Zeolite } & \multicolumn{1}{c}{$\mathrm{Si} / \mathrm{Al}$} \\
& $(\mathrm{mol} / \mathrm{mol})$ & $\mathrm{H}_{2} \mathrm{O}$ & $\mathrm{SiO}_{2}$ & $\mathrm{Al}_{2} \mathrm{O}_{3}$ & $\mathrm{Fe}_{2} \mathrm{O}_{3}$ & $\mathrm{MgO}$ & $\mathrm{CaO}$ & $\mathrm{BaO}$ & $\mathrm{SrO}$ & $\mathrm{Na}_{2} \mathrm{O}$ & $\mathrm{K}_{2} \mathrm{O}$ & $\mathrm{TiO}_{2}$ \\
\hline ATZ & 2.4 & 15.14 & 51.80 & 18.34 & 3.40 & 0.96 & 4.73 & 0.35 & 0.04 & 0.60 & 4.91 & - \\
ZS-500RW & 3.6 & - & 69.50 & 16.60 & 4.33 & 0.89 & 4.49 & - & - & 2.40 & 1.37 & 0.47 \\
ZEOSAND & 5.9 & 11.1 & 70.4 & 10.10 & 2.1 & 0.7 & 2.4 & - & - & 0.4 & 4.1 & - \\
\hline
\end{tabular}


Clinoptilolite is one of the most abundant zeolite minerals and has been widely used for heavy metals removal from waters and wastewaters (Faghihian and Bowman 2005, Park et al. 2002, Wingenfelder et al. 2005). Chabazite and phillipsite are also of commercial interest due to their favourable exchange properties (Ouki and Kavannagh 1999, Sheta et al. 2003).

Blank tests were performed to investigate the adsorption properties of the unmodified zeolites towards chromate species. Isotherm adsorption capacities were performed with $500 \mathrm{mg}$ of Zeosand or ZS-500RW zeolites and $40 \mathrm{ml}$ of $\mathrm{Cr}(\mathrm{VI})$ solutions with a concentration ranging from 50 to $500 \mu \mathrm{g} / \mathrm{L}$. After an equilibration time of 24 hours $(\mathrm{pH}=6)$ the $\mathrm{Cr}$ concentration of the solutions did not change, indicating that no significant adsorption takes place.

To generate the $\mathrm{Fe}(\mathrm{II})$-modified zeolites, the zeolitic material was treated twice with $\mathrm{FeSO}_{4} \cdot 7 \mathrm{H}_{2} \mathrm{O}$ in deionized water under dinitrogen atmosphere to ensure complete cation exchange. The resulting Fe(II) uptakes are reported in Table 3 from which it is apparent that, while ATZ and ZEOSAND showed an appreciable Fe uptake $(0.34$ and $0.54 \%$ respectively), the ZS-500RW gave a Fe uptake only slightly higher than that of the siliceous sand used as control material. The control experiment was performed with a sample of siliceous sand, $\mathrm{CEC} \approx 0$, grain size $>0.42 \mathrm{~mm}$, and it gave a $\mathrm{Fe}$ (II) uptake of $0.011 \%$ : the iron content passed from $0.007 \%$ in the untreated sand to a $0.018 \%$ after treatment with $\left.\mathrm{FeSO}_{4} \cdot 7 \mathrm{H}_{2} \mathrm{O}\right)$.

Dynamic adsorption tests were performed with a column packed with the freshly prepared modified zeolite, using a 500 $\mu \mathrm{g} / \mathrm{L} \mathrm{Cr}(\mathrm{VI})$ solution at $\mathrm{pH}=6$ to simulate a contaminated aquifer. In the following discussion we will assume that the $\mathrm{Cr}$ amount found in the effluent as assessed by AAS analyses is due only to residual $\mathrm{Cr}(\mathrm{VI})$, since its reduced form can be considered to be immobilised onto the zeolite. Different empty bed contact times (EBCT, from 1.4 to 11.8 hours) were examined with a sample of Fe(II)-modified ATZ zeolite in order to identify the best performing elution rate.

Chromium uptake was effective also at the shortest contact time, indicating an intrinsic fast abatement of $\mathrm{Cr}(\mathrm{VI})$. Breakthrough target, $5 \mu \mathrm{g} / \mathrm{L}$ for $\mathrm{Cr}(\mathrm{VI})$, occurred at about 400 pore volumes (PVs) at a flow rate of $0.040 \mathrm{~L} / \mathrm{h}$, corresponding to $23.6 \mathrm{~L}$ of effluent solution. A blank test carried out with unmodified ATZ gave immediate breakthrough, confirming the inability of the unmodified ATZ to remove $\mathrm{Cr}(\mathrm{VI})$. Unfortunately, the analysis of Fe content in the effluent revealed considerable Fe leaching from the column. The presence of $\mathrm{Fe}$ in the effluent is undesirable because: $(i)$ the overall capability in $\mathrm{Cr}(\mathrm{VI})$ removal decreases with time; (ii) the maximum acceptable Fe concentration of $200 \mu \mathrm{g} / \mathrm{L}$ set by the Italian regulation for groundwater remediation in contaminated sites (Italian D. Lgs. 152/2006) might be overcome.

Next, the effect of an increased influent ionic strength on the column performance was examined to simulate the treatment of a coastal saline groundwater. Such effect was studied by using a solution containing $500 \mu \mathrm{g} / \mathrm{L}$ of $\mathrm{Cr}(\mathrm{VI})$ and $15 \mathrm{~g} / \mathrm{L}$ of $\mathrm{NaCl}$ with a flow rate of $0.040 \mathrm{~L} / \mathrm{h}$ at $\mathrm{pH}=6$. Under these conditions the column efficiency decreased, as the saturation occurred at lower pore volumes (240 PVs against $400 \mathrm{PVs}$ ), and Fe leaching was more pronounced (Figure 1).

The performances of $\mathrm{Fe}(\mathrm{II})$-modified ZS-500RW and ZEOSAND zeolites were thus tested using a Cr(VI) $(500 \mu \mathrm{g} / \mathrm{L})$ plus $\mathrm{NaCl}(15 \mathrm{~g} / \mathrm{L})$ solution and a flow rate of $0.040 \mathrm{~L} / \mathrm{h}$. For ZS-500RW zeolite, the column test showed a very early breakthrough at about $150 \mathrm{PVs}$; Fe leaching occurred also very early indicating a rapid depletion of Fe from the support.

In the case of ZEOSAND zeolite, the column saturation occurred at $320 \mathrm{PVs}$, the highest value obtained for the zeolites tested (Figure 2). The analysis of Fe concentration in the effluent revealed a strong Fe depletion of the modified zeolite $(80 \mathrm{mg} / \mathrm{L}$ at $17 \mathrm{PVs}$ ). To evaluate the content of iron still adsorbed on the support, the completely exhausted zeolite (i.e. when the effluent concentration did not differ significantly from the influent concentration) was deeply rinsed with deionized water and then dried under vacuum: the Fe content obtained by acid extraction was $0.35 \%$ vs an initial value of $0.78 \%$, giving a ca. $55 \%$ leaching.

The Fe(II)-modified ZEOSAND packed column was used also to monitor the $\mathrm{pH}$ change of the effluent. From Figure 2 it is apparent that $\mathrm{pH}$ increases progressively from 3 to 5 as the column saturation is approached. Since the lowest $\mathrm{pH}$ was found in the early stages of elution when the Fe concentration of the effluent was the highest $(80 \mathrm{mg} / \mathrm{L} \mathrm{ca}$.), it is conceivable that the initial low $\mathrm{pH}$ may be due to the presence of acidic $\mathrm{Fe}^{\mathrm{n}+}$ species (Byrne et al. 2000, Byrne et al. 2005, Sass and Rai 1987, Stefánsson 2007).

It is worth noting that the zeolites were active even though the influent solution was under air: this indicates that also in our operating conditions $\mathrm{Fe}(\mathrm{II})$ oxidation by $\mathrm{O}_{2}$ is slower than that by $\mathrm{Cr}(\mathrm{VI})$. It is known that the relative rates of $\mathrm{Cr}(\mathrm{VI})$ reduction and $\mathrm{Fe}(\mathrm{II})$ aerobic oxidation are dependent both on the $\mathrm{pH}$ and on the concentration of the species: $\mathrm{Fe}$ (II) aerobic oxidation becomes faster at $\mathrm{pH}$ higher than 8 or very low $\mathrm{Cr}(\mathrm{VI})$ concentrations $(<<10 \mathrm{mM})$ (Schlautman and Han 2001 and references therein, Sung and Morgan 1980).

A comparison of the zeolite performances shows that Zeosand ( $80 \%$ clinoptilolite) is the best one in terms of both $\mathrm{Fe}(\mathrm{II})$ adsorption $(0.54 \mathrm{wt} \%)$ and $\mathrm{Cr}$ removal $(90 \mathrm{mg} \mathrm{Cr} / \mathrm{Kg}$

Table 3. Comparison of three natural zeolites for $\mathrm{Cr}(\mathrm{VI})$ abatement

\begin{tabular}{cccc}
\hline Zeolite & $\begin{array}{c}\text { Fe(II) uptake } \\
(\mathbf{w t} \%)\end{array}$ & Breakthrough V. (PV) & $\begin{array}{c}\text { Cr(VI) removal } \\
\left(\mathbf{m g}_{\mathrm{cr}_{\mathbf{r}}} \mathbf{K g}_{\text {zeolite }} \mathbf{)}\right.\end{array}$ \\
\hline ATZ & 0.34 & 240 & 80 \\
ZS-500RW & 0.03 & 150 & 47 \\
ZEOSAND & 0.54 & 320 & 90 \\
\hline
\end{tabular}

$[\mathrm{Cr}]_{0}=500 \mu \mathrm{g} / \mathrm{L} ;[\mathrm{NaCl}]=15 \mathrm{~g} / \mathrm{L} ;$ flow rate $0.040 \mathrm{~L} / \mathrm{h}$. 


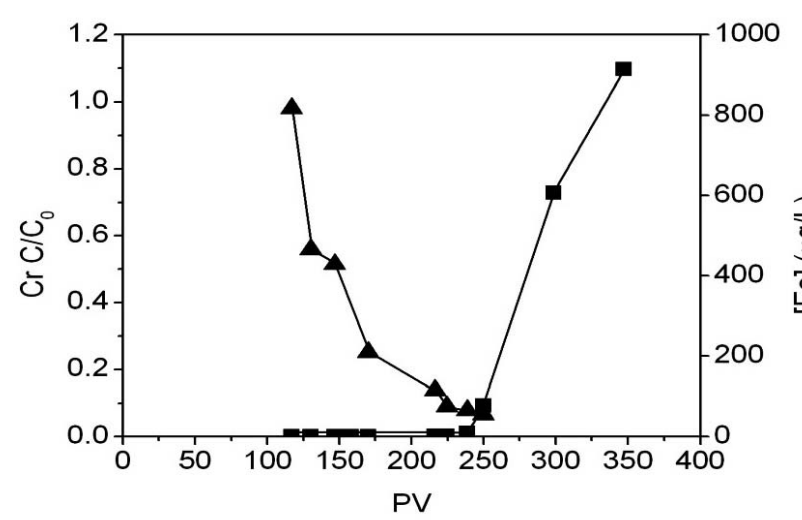

Fig. 1. Fe(II)-modified ATZ packed column; $\mathrm{Cr}(\mathrm{VI}), 500 \mu \mathrm{g} / \mathrm{L}$; $\mathrm{NaCl}, 15 \mathrm{~g} / \mathrm{L}$;

п: breakthrough curve; $\boldsymbol{\Delta}$ : Fe concentration in the effluent

zeolite). ATZ (79\% phillipsite/chabazite) showed a similar behaviour, with a $0.34 \mathrm{wt} \%$ of Fe(II) adsorption and a maximum $\mathrm{Cr}$ removal of $80 \mathrm{mg} \mathrm{Cr} / \mathrm{Kg}$ zeolite. These two zeolites have a similar granulometry and CEC, but Zeosand has a broader $\mathrm{pH}$ range of stability that makes it particularly suitable for the exchange with acidic Fe(II) solutions (ATZ gave a significant amount of degradation mud during the exchange process with $\mathrm{Fe}$ (II) solutions, presumably due to its lower stability with respect to Zeosand or ZS-500RW zeolites). On the contrary, ZS-55RW (90\% Chabazite) showed a very low Fe(II) uptake and correspondingly a scarce efficiency in $\mathrm{Cr}$ removal despite its lower $\mathrm{Si} / \mathrm{Al}$ ratio and higher $\mathrm{CEC}$.

Very recently, the opportunity to take use of Clinoptilolite zeolite with surface modification by $\mathrm{Fe}(\mathrm{II})$ to enhance its capability of removing $\mathrm{Cr}(\mathrm{VI})$ from contaminated ground water was investigated ( $\mathrm{Lu}$ et al. 2013) under conditions slightly different from the present study. It was reported that $74 \%$ Clinloptilolite zeolite modified to a loading level of $0.3 \%_{\mathrm{w}} \mathrm{Fe}$ content resulted in a $\mathrm{Cr}(\mathrm{VI})$ sorption capability up to $0.3 \mathrm{mg} / \mathrm{g}$ (Lu et al. 2013).

The present work is generally in accordance with what developed in the previous study, even if no mention about the residual $\mathrm{Fe}$ amount in solution (in order to evaluate the iron leaching) was previously reported (Lu et al. 2013).

\section{Conclusions}

This work showed that three Fe(II) modified natural zeolites tested in continuous flow columns are active supports for $\mathrm{Cr}(\mathrm{VI})$ abatement, lowering its concentration below the European regulation level.

The major drawback of this process is the extensive leaching of iron from the column, which is more severe in the early stages of column operation. Tests on real contaminated ground water could provide useful information about the longevity of the system for the field application of these materials.

\section{Acknowledgements}

Politecnico di Bari (F.R.A. research funding) is acknowledged for financial support.

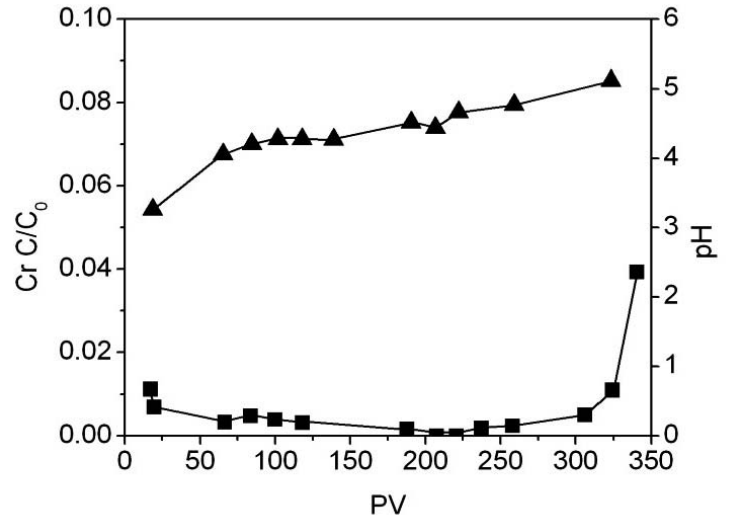

Fig. 2. Fig. 2. Fe(II)-modified ZEOSAND packed column; $\mathrm{Cr}(\mathrm{VI}), 500 \mu \mathrm{g} / \mathrm{L} ; \mathrm{NaCl}, 15 \mathrm{~g} / \mathrm{L}$;

m: breakthrough curve; $\boldsymbol{\Delta}: \mathrm{pH}$ of the effluent

\section{References}

Barrer, R.M. (1978). Zeolites and Clay Minerals as Sorbents and Molecular Sieves, London: Academic Press, London 1978.

Bowman, R.S. \& Helferich, R. (2001). Production and article of iron/surfactant-modified zeolite pellets to retain and destroy water pollutants, U.S. Patent No. 6,261,986 B1, 17 July 2001. Washington, D.C.: U.S. Patent and Trademark Office.

Byrne, R.H., Luo, Y.-R. \& Young, R.W. (2000). Iron hydrolysis and solubility revisited: observations and comments on iron hydrolysis characterizations, Marine Chemistry, 70, pp. 23-35.

Byrne, R.H., Yao, W., Luo, Y.-R. \& Wang, B. (2005). The dependence of $\mathrm{Fe}$ (III) hydrolysis on ionic strength in $\mathrm{NaCl}$ solutions, Marine Chemistry, 97, pp. 34-48.

Campos, V., Morais, L.C. \& Buchler, P.M. (2007). Removal of chromate from aqueous solution using treated natural zeolite, Environmental Geology, 52, pp. 1521-1525.

Dimirkou, A. \& Doula, M.K. (2008). Use of clinoptilolite and an Fe-overexchanged clinoptilolite in $\mathrm{Zn}^{2+}$ and $\mathrm{Mn}^{2+}$ removal from drinking water, Desalination, 224, pp. 280-292.

Doula, M.K. (2007). Synthesis of a clinoptilolite-Fe system with high $\mathrm{Cu}$ sorption capacity, Chemosphere, 67, pp. 731-740.

Eary, L.E. \& Rai, D. (1987). Kinetics of chromium(III) oxidation to chromium(VI) by reaction with manganese dioxide, Environmental Science \& Technology, 27, pp. 1187-1193.

Eary, L.E. \& Rai, D. (1988). Chromate removal from aqueous wastes by reduction with ferrous ion, Environmental Science \& Technology, 22, pp. 972-977.

Erdogan, B.C. \& Ulku, S. (2012). Cr(VI) sorption by using clinoptilolite and bacteria loaded clinoptilolite rich mineral, Microporous Mesoporous Mater, 152, pp. 253-261.

Faghihian, H. \& Bowman, R.S. (2005). Adsorption of chromate by clinoptilolite exchanged with various metal cations, Water Research, 39, pp. 1099-1104.

Fruchter, J. (2002). In situ treatment of chromium-contaminated groundwater, Environmental Science \& Technology, 36, pp. 464A-472A.

Gode, F. \& Pehlivan, E. (2005). Removal of Cr(VI) from aqueous solution by two Lewatit-anion exchange resins, Journal of Hazardous Materials, 119, pp. 175-182.

Hu, S.J., Buerge, I.J. \& Weidler, P.G. (1997). Transformations of chromium in the environment, Analysis, 25, pp. 12-15.

Hwang, I., Batchelor, B., Schlautman, M.A. \& Wang, R. (2002). Effects of ferrous iron and molecular oxygen on chromium(VI) 
redox kinetics in the presence of aquifer solids, Journal of Hazardous Materials, 92, pp. 143-159.

Inglezakis, V. J., Loizidou, M. D. \& Grigoropoulou, H. P. (2003). Ion exchange of $\mathrm{Pb}^{2+}, \mathrm{Cu}^{2+}, \mathrm{Fe}^{3+}$, and $\mathrm{Cr}^{3+}$ on natural clinoptilolite: selectivity determination and influence of acidity on metal uptake, Journal of Colloid and Interface Science, 261, pp. 49-54.

Kiser, J.R. \& Manning, B.A. (2010). Reduction and immobilization of chromium(VI) by iron(II)-treated faujasite, Journal of Hazardous Materials, 174, pp. 167-174.

Kotaś, J. \& Stasicka, Z. (2000). Chromium occurrence in the environment and methods of its speciation, Environmental Pollution, 107, pp. 263-283.

Leyva-Ramos, R., Jacobo-Azuara, A., Diaz-Flores, P.E., Guerrero-Coronado, R.M., Mendoza-Barron, J. \& Berber-Mendoza, M.S. (2008). Adsorption of chromium(VI) from an aqueous solution on a surfactant-modified zeolite, Colloids and Surfaces A: Physicochemical and Engineering Aspects, 330, pp. 35-41.

Li, Z., Jones, H.K., Bowman, R.S. \& Helferich, R. (1999). Enhanced reduction of chromate and PCE by pelletized surfactant-modified zeolite/zerovalent iron, Environmental Science \& Technology, 33, pp. 4326-4330.

Li, Z. (2006). Chromate transport through surfactant-modified zeolite columns, Groundwater Monitoring \& Remediation, 26, pp. 117-124.

Li, Z., Jones, H.K., Zhang, P. \& Bowman, R.S. (2007). Chromate transport through columns packed with surfactant-modified zeolite/zero valent iron pellets, Chemosphere, 68, pp. 1861-1866.

Liguori, B., Cassese, A. \& Colell, A. (2006). Safe immobilization of $\mathrm{Cr}(\mathrm{III})$ in heat-treated zeolite tuff compacts, Journal of Hazardous Materials, 137, pp. 1206-1210.

Litz, J.E. (2006). Hexa-valent chromium removal from aqueous media using ferrous-form zeolite materials, U.S. Patent No. 7,105,087 B2, 12 September 2006. Washington, D.C.: U.S. Patent and Trademark Office.

Loyaux-Lawniczak, S., Lecomte, P. \& Ehrhardt, J.-J. (2001). Behavior of hexavalent chromium in a polluted groundwater: redox processes and immobilization in soils, Environmental Science \& Technology, 35, pp. 1350-1357.

Lu, G., Li, Z., Jiang, W.-T., Ackley, C., Fenske, N. \& Demarco, N. (2013). Removal of Cr(VI) from water using Fe(II) modified natural zeolites, Chemical Engineering Research and Design, CHERD-1335, 92,2, pp. 384-390

Ludwig, R.D., Su, C., Lee, T.R., Wilkin, R.T., Acree, S. D., Ross, R.R. \& Keeley, A. (2007). In situ chemical reduction of $\mathrm{Cr}(\mathrm{VI})$ in groundwater using a combination of ferrous sulfate and sodium dithionite: a field investigation, Environmental Science \& Technology, 41, pp. 5299-5305.

Mackay, D.M. \& Cherry, J.A. (1989). Groundwater contamination: pump-and-treat remediation, Environmental Science \& Technology, 23, pp. 630-636.

Martin, T.A. \& Kempton, J.H. (2000). In situ stabilization of metal-contaminated groundwater by hydrous ferric oxide: an experimental and modeling investigation, Environmental Science \& Technology, 34, pp. 3229-3234.

Meir, M.V., Callejas, R.L., Gehr, R., Cisneros, B.E.J. \& Alvarez, P.J.J. (2001). Heavy metal removal with Mexican clinoptilolite: Multi-component ionic exchange, Water Research, 35, pp. 373-378.

Misaelides, P., Zamboulis, D., Sarridis, P., Warchoł, J. \& Godelitsas, A. (2008). Chromium (VI) uptake by polyhexamethylene-guanidine-modified natural zeolitic materials, Microporous and Mesoporous Materials, 108, pp. 162-167.

Ouki, S.K. \& Kavannagh, M. (1999). Treatment of metals-contaminated wastewaters by use of natural zeolites, Water Science and Technology, 39, pp. 115-122.
Palmer, C.D. \& Wittbrodt, P.R. (1991). Processes affecting the remediation of chromium-contaminated sites, Environmental Health Perspectives, 92, pp. 25-40.

Park, J.-B., Lee, S.-H., Lee, J.-W. \& Lee, C.-Y. (2002). Lab scale experiments for permeable reactive barriers against contaminated groundwater with ammonium and heavy metals using clinoptilolite (01-29B), Journal of Hazardous Materials, 95, pp. 65-79.

Patterson, R.R., Fendorf, S. \& Fendorf, M. (1997). Reduction of hexavalent chromium by amorphous iron sulphide, Environmental Science \& Technology, 31, pp. 2039-2044.

Qin, G., Mcguire, M.J., Blute, N.K., Seidel, C. \& Fong, L. (2005). Hexavalent chromium removal by reduction with ferrous sulfate, coagulation, and filtration: a pilot-scale study, Environmental Science \& Technology, 39, pp. 6321-6327.

Rai, D., Sass, B.M. \& Moore, D.A. (1987). Chromium(VI) hydrolysis constants and solubility of chromium hydroxide, Inorganic Chemistry, 26, pp. 345-349.

Rama Krishna, K. \& Philip, L. (2005). Bioremediation of Cr(VI) in contaminated soils, Journal of Hazardous Materials, 121, pp. 109-117.

Rengaraj, S., Joo, C.K., Kim, Y. \& Yi, J. (2003). Kinetics of removal of chromium from water and electronic process wastewater by ion exchange resins: $1200 \mathrm{H}, 1500 \mathrm{H}$ and IRN97H, Journal of Hazardous Materials, 102, pp. 257-275.

Rhodes, C.J. (2007). Zeolites: physical aspects and environmental applications, Annual Reports of the Progress of Chemistry C, 103, pp. 287-325.

Robson, H. (2001). Verified Syntheses of Zeolitic Materials, Elsevier Science B.V., Amsterdam, 2001.

Sass, B.M. \& Rai, D. (1987). Solubility of amorphous chromium(III)-iron(III) hydroxide solid solutions, Inorganic Chemistry, 26, pp. 2228-2232.

Schlautman, M.A. \& Han, I. (2001). Effects of $\mathrm{pH}$ and dissolved oxygen on the reduction of hexavalent chromium by dissolved ferrous iron in poorly buffered aqueous systems, Water Research, 35, pp. 1534-1546.

Sheta, A.S., Falatah, A.M., Al-Sewailem, M.S., Khaled, E.M., Sallam, A.S.H. (2003). Sorption characteristics of zinc and iron by natural zeolite and bentonite, Microporous and Mesoporous Materials, 61, pp. 127-136.

Stefánsson, A. (2007). Iron(III) hydrolysis and solubility at $25^{\circ} \mathrm{C}$, Environmental Science \& Technology, 41, pp. 6117-6123.

Sung, W. \& Morgan, J.J. (1980). Kinetics and products of ferrous iron oxygenation in aqueous systems, Environmental Science \& Technology, 14, pp. 561-568.

Tokunaga, T.K., Wan, J., Firestone, M.K., Hazen, T.C., Olson, K.R., Herman, D.J., Sutton, S.R. \& Lanzirotti, A. (2003). In situ reduction of chromium(VI) in heavily contaminated soils through organic carbon amendment, Journal of Environmental Quality, 32, pp. 1641-1649.

Vignola, R., Sisto, R., Grillo, G., Cova, U. \& Cesti, P. (2007). Process for the treatment of contaminated water by means of a bifunctional system consisting of iron and zeolites, International Patent WO 2007/054358 A1, 18 May 2007.

Vignola, R., Cova, U., Della Penna, G. \& Sisto, R. (2008). Process for the treatment of contaminated water based on the use of apolar zeolites having different characteristics, U.S. Patent No. 7,341,665 B2, 11 March 2008. Washington, D.C.: U.S. Patent and Trademark Office.

Wingenfelder, U., Hansen, C., Furrer, G. \& Schulin, R. (2005). Removal of heavy metals from mine waters by natural zeolites, Environmental Science \& Technology, 39, pp. 4606-4613.

Wu, D., Sui, Y., He, S., Wang, X., Li, C. \& Kong, H. (2008). Removal of trivalent chromium from aqueous solution by zeolite synthesized from coal fly ash, Journal of Hazardous Materials, 155 , pp. $415-423$. 
Yang, J.E., Kim, J.S., Ok, Y.S. \& Yoo, K.R. (2007). Mechanistic evidence and efficiency of the $\mathrm{Cr}(\mathrm{VI})$ reduction in water by different sources of zerovalent irons, Water Science and Technology, 55, pp. 197-202.

Zayed, A.M. \& Terry, N. (2003). Chromium in the environment: factors affecting biological remediation, Plant and Soil, 249, pp. 139-156.
Zeng, Y., Woo, H., Lee, G. \& Park, J. (2010). Adsorption of Cr(VI) on hexadecylpyridinium bromide (HDPB) modified natural zeolites, Microporous Mesoporous Mater, 130, pp. 83-91.

Zhao, D., SenGupta, A.K. \& Stewart, L. (1998). Selective removal of $\mathrm{Cr}(\mathrm{VI})$ oxyanions with a new anion exchanger, Industrial \& Engineering Chemistry Research, 37, pp. 4383-4387. 